\title{
MACROECONOMICS OF MICROFINANCE: HOW DO THE CHANNELS WORK?
}

\author{
Nargiza Maksudova
}
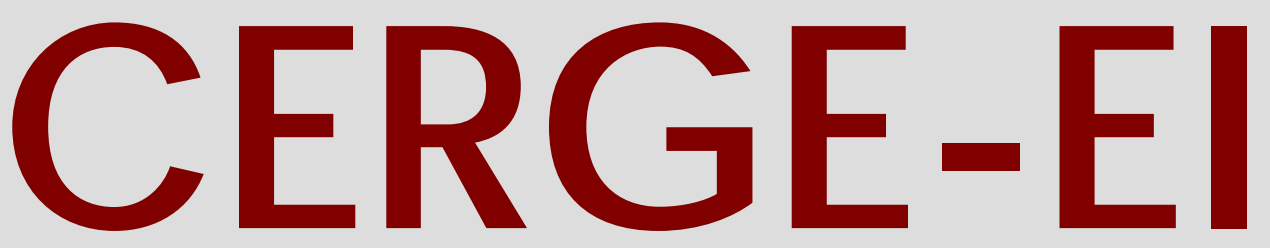

Charles University Centerfor Economic Research and Graduate Education Academy of Sciences of the Czech Republic Ec onomic s Institute 


\section{Working Paper Series 423 (ISSN 1211-3298)}

\section{Macroeconomics of Microfinance: How Do the Channels Work?}

Nargiza Maksudova

CERGE-EI

Prague, October 2010

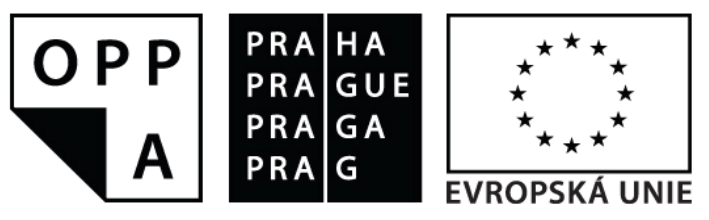

EVROPSKÝ SOCIÁLNÍ FOND

PRAHA \& EU: INVESTUJEME DO VAŠÍ BUDOUCNOSTI 
ISBN 978-80-7343-222-5 (Univerzita Karlova. Centrum pro ekonomický výzkum a doktorské studium)

ISBN 978-80-7344-212-5 (Národohospodářský ústav AV ČR, v.v.i.) 


\title{
Macroeconomics of Microfinance: How Do the Channels Work?*
}

\author{
Nargiza Maksudova ${ }^{\dagger}$
}

CERGE-EI

\begin{abstract}
Recent changes in the microfinance landscape are characterized by increasing patterns of its integration with national financial systems and entry of commercial banks. Microfinance is no longer perceived as an isolated marginal sector of informal intermediation but rather constitutes particular lower-end segment of the broader financial system. Addressing the limited research on the interaction of microfinance with the broader economy I aim to reveal whether and how microfinance is transferred to growth through the identification of causality. I also consider the indirect impact of microfinance through its complement/substitute nature with mainstream banks. The empirical analysis is based on data from 1433 microfinance institutions pooled into 102 countries on which I perform a Granger-causality test using the Arellano and Bond (1991) methodology. The results indicate different transfer channels of microfinance to growth for middle and low-income countries, implying that the strength of the impact depends on the underlying level of development. The nature of microfinance interaction with commercial banks and money aggregates is of significant importance due to competition, spillover effects and (counter) cyclical influence, which hints at the potential of microfinance institutions to affect financial sector structure in the long-term.
\end{abstract}

\begin{abstract}
Abstrakt
Současné změny $\mathrm{v}$ mikrofinancování jsou charakterizovány vzrůstající integrací s národními finančními systémy a větším zapojením bank. Tudíž mikrofinance už nejsou vnímány jako okrajový sektor zprostředkovávající informace, ale spíše jako podstatná komponenta finančního sektoru. Jelikož je doposud udělaný výzkum věnující se tomuto oboru malý, v této práci se snažím ukázat vliv mikrofinancí na růst prostřednictvím studie kauzality. Rovněž zkoumám nepř́mý dopad mikrofinancí prostřednictvím povahy jeho doplňků a substitutů vzhledem $\mathrm{k}$ bankovnictví hlavního proudu a vývoji finančního sektoru. Empirická analýza je založená na datech z 1433 mikrofinancujících institucí ze 102 zemí, na kterých provádím test Grangerovy kauzality za použití Arellano-Bond (1991) metodologie. Výsledky naznačují existenci různých přenosových kanálů, kterým mikrofinance ovlivňují růst nízko a středně př́ijmových zemí, což ukazuje, že dopad mikrofinancí závisí na rozvinutosti dané země. Podstata interakce mikrofinancí s bankovnictvím hlavního proudu je důležitá vzhledem k vzrůstající důležitosti vlivem konkurence, efektů přelévání a (proti)-cyklických vlivů, které naznačují, jakým způsobem mohou mikrofinance ovlivnit strukturu trhu v dlouhodobém měřítku.
\end{abstract}

Keywords: microfinance, economic growth, financial intermediation, dynamic panel JEL Classifications: G15, G21, O16, O57

\footnotetext{
* I would like to thank Jan Hanousek, Randall K. Filer, Evžen Kočenda, Evangelia Vourvachaki, and the participants of Spring Meeting of Young Economists, $15^{\text {th }}$ conference, for helpful comments and suggestions. All errors remaining in this text are the responsibility of the author. The support from the World Bank Research Fellowship, grants from GA UK (project No. 52010) and SVV-2010-261 801 is greatly acknowledged.

$\dagger$ E-mail: nargiza.maksudova@cerge-ei.cz.

$¥$ CERGE-EI is a joint workplace of Charles University in Prague and Academy of Science of the Czech Republic. Address: CERGE-EI, P.O. Box 882, Politických vězňů 7, Prague 1, 111 21, Czech Republic.
} 


\section{Introduction and Motivation}

The aim of the paper is to unveil the impact of microfinance on the broader economy through the identification of transfer channels and the extent to which it affects the market structure of the financial sector. The research agenda is of acute importance given the rapid expansion of microfinance and its ever increasing interaction with financial sector.

Since the 1970s microfinance has been growing rapidly with the aim to lift people out of poverty and promote economic growth. Over the past decades, however, microfinance transformed vastly and nowadays represents a significant and self-sustaining industry of more than 3000 reported microfinance finance institutions (MFIs) servicing 154 million clients worldwide (Microcredit Summit Campaign, 2009). Nowadays microfinance is no more perceived being a "magic bullet" automatically lifting poor people out of poverty through microenterprise. Rather it focuses on the "poverty graduation" of low-income households by delivering them a variety of good-quality financial services.

The currently observed dramatic changes in the microfinance landscape are driven by two important phenomena. First, there is a growing trend of mature MFIs transforming from being NGOs to licensed and regulated financial institutions, thus integrating more with national financial systems (for example ACLEDA Bank in Cambodia; Xac Bank in Mongolia; Spandana and SKS in India). Second, the observed profitability and new market niche lures the entry of commercial banks into the microfinance segment by offering new products, establishing separate branches or providing external financing for MFIs (for example ICICI Bank, ABN-AMRO, Citibank, HSBC in India and China and ANZ Bank in Fiji). All of these factors signal that microfinance is no more an isolated marginal sector of informal means of financing but rather constitutes a separate, lower-end segment of the broader financial system and hence a locomotive of economic growth. Despite the fact, the net contribution of microfinance to the broader economy remains ambiguous given complementary or rivalry relationships. Additional negative externalities come from excessive risk-taking behavior, increasing delinquency, cross-subsidy of microfinance loans and the deteriorating management quality of certain microfinance institutions (Chen et al., 2010).

Despite the global promotion of financial inclusion current estimates show that still 2.5 billion adults, roughly half of the world, are unbanked. Of these, $62 \%$ (or 2.2 billion) reside in Asia, Africa, Latin America and the Middle East (Dalal et al., 2009). Such drastic figures signal a large untapped demand for banking services and profit opportunities indicating that microfinance will continue to expand diffusing through specialist MFIs and banks. However, the speed and the nature of these processes are not clear enough. What are the transfer 
channels of microfinance to the broader economy and how do they differ by the development stage of the country? Is there any capacity of microfinance institutions to affect financial sector infrastructure? These are the specific questions that I address in the paper.

The analysis of the macroeconomic factors influencing MFIs' performance is an emerging trend in the mainstream literature. The focus of existing studies so far can be divided into three broad categories: (a) the analysis of MFI specific determinants of performance such as contract design, lending methodology and corporate governance (Hartarska, 2005; Hartarska \& Nadolnyak, 2007, 2008; Hermes et al., 2008, 2009; Caudill et al., 2009), (b) macroeconomic factors determining the uneven distribution of MFIs and the impact of country-level aggregates such as growth, inflation, poverty and corruption (Marconi \& Mosley, 2005; Honohan, 2004, 2008; Vanroose, 2007, 2008; Vanroose \& D'Espallier, 2009) and (c) the analysis of macro-institutional determinants of MFIs' success by disentangling the impact of MFI sustainability factors and the external environment they operate in (Krauss \& Walter, 2008; Ahlin et al., 2010).

Conversely in this paper I study the impact of microfinance itself on the broader economy thus filling the gap in the literature. First, I perform country-level analysis and then decompose infrastructure-level impact of microfinance. A particular value-added comes from going beyond a summary of stylized facts based on correlation and omitted variables analysis which is dominant in the mentioned studies. I rather focus on causal impact of microfinance to macro environment and aim to disentangle the reverse relationship between the two using a Granger-causality framework.

The theoretical approach of the paper is built on a general finance-and-growth nexus where microfinance is seen as a new pillar capturing informal intermediation and directly contributing to financial sector development. More specifically current industrialization of microfinance enables to quantify and measure the contribution of informal sector which is vast in less-developed economies and has been in the shadow for many decades.

The impact of microfinance to economic growth is perceived through direct and indirect channels. The direct channel of microfinance is based on poverty reduction, welfare increase and production value added from entrepreneurship activities of the poor. Therefore I believe that economic growth as an aggregate measure captures the direct contribution of microfinance. Under indirect channel to growth microfinance contributes to an increase in liquid liabilities through financial deepening and the development of retail banking system. Depending on complement/rival relationship of microfinance with mainstream banking the degree and the maturity of the financial sector is shaped which is then transferred to growth 
accordingly (Cull et al., 2009; Hermes et al., 2009). Acknowledging the importance of the indirect channel I also investigate the extent to which MFIs affect the financial sector infrastructure through changes in the demographic and geographic penetration of credit intermediaries.

According to the results there are different microfinance transfer mechanisms for middleand low-income countries. Particularly I find positive Granger-causality running directly from microfinance to economic growth. The transfer dynamics, however, depends on the development stage of the country. The derived heterogeneity of the channels complies with the observed patterns across countries and the existing empirical findings. It might also capture different stage of microfinance industrialization. Microfinance indirect channel is captured by its interaction with money and mainstream banking indicators. The puzzling nature of these interactions hints at microfinance negative externalities, spillovers effects and (counter) cyclical influence in the times of macroeconomic shocks and therefore should be investigated more.

The rest of the paper is organized as follows. In section 2 I define the theoretical framework of microfinance transfer channels, review empirical findings and formulate the hypothesis. Section 3 presents the methodology, which is based on the Granger-causality test using Arellano and Bond (1991) instrumental variables approach. In section 4 I present the dataset, variables and transformations performed. Section 5 is a discussion of the results and their implications for real-world implementation. The last section concludes.

\section{Microfinance Channels}

\subsection{Theoretical predictions and empirical evidence}

As a motivation I plot the observed volatility of microfinance and its dynamic relationship with macroeconomic fundamentals. Figure 1 visualizes the dynamics of microfinance evolution, captured by the gross loan portfolio of MFIs, ${ }^{1}$ and contrasts it with the growth rates of fundamentals. The plots are year averages for middle- (left side) and low-income (right side) countries for 1995-2009 time span.

\footnotetext{
${ }^{1}$ The data is obtained from Microfinance Information eXchange (MIX) which is the World Bank and CGAP platform aiming to promote information exchange on microfinance worldwide.
} 
Figure 1: Dynamic relationship of microfinance with macroeconomic indicators, middle-income (left) and low-income (right) countries
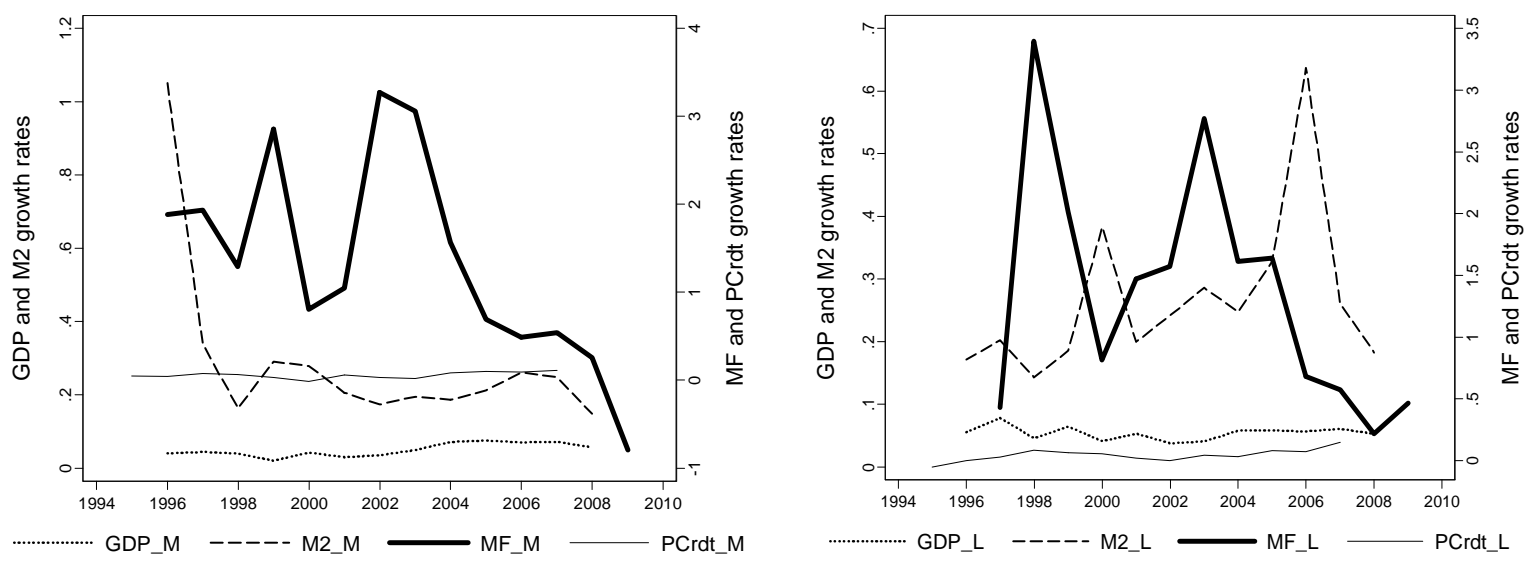

It is visible that microfinance loan portfolio (MF) and monetary base (M2) growth rates are higher than that of GDP and private credit (PCrdt). While the banking sector is fairly stable for the entire time span, microfinance grows faster, tackling untapped clientele. I also observe dramatic differences in the dynamics between low- and middle-income countries. The gap between private credit capturing mainstream banking and the microfinance loan portfolio is larger for low-income countries and the volatility of money supply is high. An important conclusion from these observations is that microfinance transmission channels might differ by income groups and there is an uneven degree of microfinance provision within countries (Rhyne \& Otero, 2006).

Based on the observed variations I proceed further by defining the channels through which microfinance is transferred to growth. Figure 2 is the best illustration of the theoretical base for the analysis and further discussion revolves around three arrows (A, B and C) that link microfinance with external environment.

Figure 2: Microfinance channels

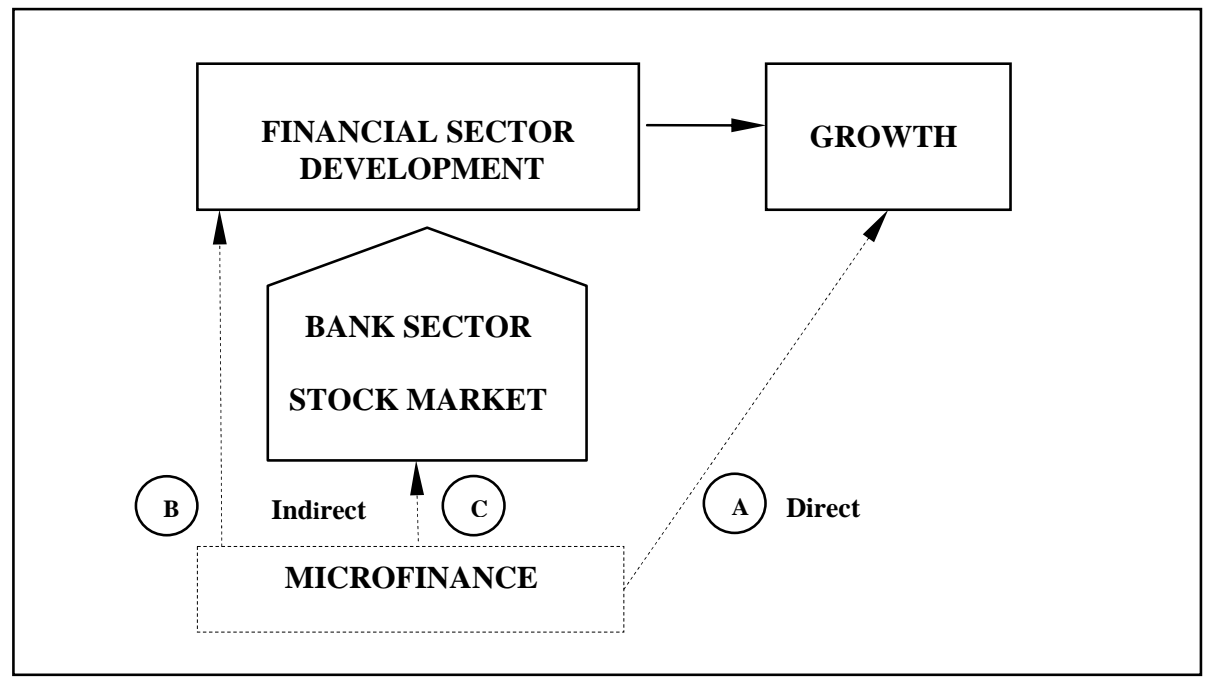


The positive contribution of financial sector development to economic growth through banks and equity markets nowadays is a proven hypothesis and has been widely tested at the cross-country, industry and firm levels (King \& Levine, 1993; La Porta et al., 1998; Rajan \& Zingales, 1998). While the main role of the financial sector is to reduce information, enforcement and transaction costs, Levine (2004) outlines five functions that the financial system serves in facilitating growth: savings mobilization, provision of investment information, monitoring/governance, risk management, facilitation in goods and service exchange. Through these functions the financial sector not only promotes private sector development but also supports the public sector, infrastructure and the household's ability to invest in human capital and consumption smoothing.

In this regard microfinance contributes directly to economic growth (arrow A) through production created by small entrepreneurship, improvements in human development indicators (health, nutrition, education) and a reduction in poverty (Ravallion, 2001). For instance Kai and Hamori (2009) analyze 61 developing countries and provide evidence that microfinance tends to reduce income inequality directly by easing the credit constraints of the poor. Conversely, higher income inequality is associated with fairly high default on microfinance loans and higher interest rates (Vanroose \& D'Espallier 2009; Ahlin et al., 2010). In reverse, the macroeconomic environment might shape the development path of microfinance institutions. Ahlin et al. (2010) document that MFIs recover costs better where economic growth is higher because of the associated lower default rate and operating costs. Not only the level of growth but its composition also matters: microfinance loans grow faster where the share of the manufacturing sector is large, foreign direct investment is large and labor force participation is extensive (Ahlin et al., 2010; Leegwater \& Shaw, 2008).

Microfinance indirectly contributes to economic growth (arrow B) through its interaction with financial markets. Microfinance institutions increase access to finance of the poor, integrate better households' financial needs and the most important - make "shadow" financial intermediation formal. Therefore the second contribution of microfinance is claimed to be captured by an increase of money circulation in the economy. Barr (2005) provides additional reasons to view financial development through the lens of microfinance: (i) financially sustainable MFIs promote market deepening that in turn advances financial development, (ii) microfinance is a powerful tool in countries with poor governance that hinders the proper functioning of other development programs and (iii) microfinance supports domestic financial reforms by breaking down constraints. 
The maturity of the financial sector in turn affects performance of MFIs. Beck et al. (2004) argue that even when financial development does not touch poor people directly it nevertheless promotes aggregate economic growth, thus benefiting the poorest in a disproportionately better way. Therefore it is expected that in countries with a better developed financial sector microfinance will also be more efficient and more active. Hermes et al. (2009) investigate the direction of causality between country's financial development and MFIs' efficiency through cost reduction. Using data on 435 MFIs for 1997-2007 the authors find that a stronger financial environment tends to generate more efficient MFIs, as intense banking competition provides incentives for MFIs to improve their operational efficiencies. Ahlin et al. (2010) find that greater financial depth is strongly associated with lower default and operating costs of MFIs, thus benefiting in the end micro-borrowers.

Finally the nature of the interaction between banks and MFIs (so called "micro-banks") shapes the landscape of financial sector development. Therefore I consider the microfinance indirect transfer channel (arrow $\mathbf{C}$ ) to economic growth running through its interaction with commercial banks. The market failure hypothesis suggests microfinance normally is a good complement to mainstream banking by filling in the gaps where standard banking services are not used. Therefore the rapid growth of the microfinance segment signals weaknesses in the formal banking sector. In such cases MFIs tend to be a substitute for conventional banks, thus creating pathology.

Friendly partnership or rival relationship between banks and micro-banks is strongly associated with the degree of competition on the market, which could go both ways. From the conventional banks' perspective, increasing banking competition pushes them to look for new markets and a wider clientele. Engaging in microfinancing, which has been shown to be profitable, is seen as a promising opportunity for banks to serve a large demand for credit in developing countries that MFIs are unable to meet fully on their own (Hermes et al., 2008). From the perspective of the microfinance community, banks' entry into microfinance is expected to be short and shallow (Rhyne \& Lopez 2003). First, it may take too much time for banks to raise new microfinance business to a profitable level and hence the banks might decide against entering at all. The post-entry exit of banks from microfinance could also be very costly or banks may move up the market by increasing the loan amount. Empirically investigating this claim Cull et al. (2009) find positive and robust evidence of competition from formal banks pushing micro-banks. The intensity of the competition is associated with micro-banks serving poorer markets and more women. 
All of these facts characterize the nature of microfinance contrition to economic growth passing indirectly (arrow C) through its interaction with mainstream banking. Whether this interaction is in the form of a friendly partnership or fierce competition will transfer to economic growth respectively.

To summarize this section, little is known about how microfinance is transferred to growth and its dynamics. Moreover due to potential reverse causality present in all three channels (arrows A, B and C) the net causal effect of microfinance remains ambiguous. Therefore I proceed further with an empirical test and identification of causal impact.

\subsection{Hypotheses and key variables}

Based on the definitions of microfinance direct and indirect transmission channels above I formulate the following hypotheses for further estimation:

\section{$\mathrm{H}_{1}$ : Microfinance causes economic growth.}

First hypothesis in fact represents the direct channel of microfinance (arrow A) to economic growth. From the discussion above the direction of causality could go both ways. However, I focus on the presence and the extent of causality running from microfinance to economic growth. Moreover while estimating the channels I consider the dynamic relationship between the variables and not the levels. As such, microfinance is captured by two indicators: (a) the growth rate of the gross loan portfolio (MFp) defined as the intensive growth of microfinance institutions and (b) the growth in the number of MFI borrowers (MFb) defined as an extensive margin (Ahlin et al., 2010). Economic growth is measured by the annual growth rate of real GDP. Important note is that I aggregate MFI-level data for each country by taking year averages, which makes this paper different from previous studies. The country-level approach is essential to unveil the macro effects and smooth MFI institutional unobserved fixed effects.

$\mathrm{H}_{2}$ : Microfinance causes increase in money supply.

Based on the definition of indirect channel (arrow B) causal impact of microfinance is perceived through the formalization of shadow finance and the financial deepening of microfinance institutions. In countries where microfinance has a long enough history and has reached a particular level of industrialization, I expect to detect its significant effect on broad monetary aggregates. I also expect that the nature of their interaction will shape the path of the microfinance to economic growth. The monetary base is captured by growth in M2 which includes liquid cash (M1), savings, small time deposits and overnight repos at commercial banks and non-institutional money market accounts. As part of the sensitivity analysis I also 
employ a broader definition of money, namely M3, which consists of M2 plus large time deposits and repos of maturity greater than one day.

\section{$\mathrm{H}_{3}$ : Microfinance (positively/negatively) affects commercial banks.}

The third hypothesis reflects indirect channel (arrow C) where microfinance is transferred to growth through its interaction with commercial banks. The presence of commercial banks is captured by the growth in the ratio of private credit issued by deposit money banks to GDP (PCredit) which also determines financial depth. The complementary or substitution nature of the microfinance-banks relationship is judged by the sign of the interaction term. I also distinguish between the total effect and the partial effect of the microfinance impact. The total effect represents the sum of its own effect and the effect when it is interacted with banking indicators. The further interpretation of these effects is built on distinguishing between the economy-wide effects of microfinance (i.e. the total effect) and the extent of its impact on financial sector development (i.e. the own effect).

Based on observed volatilities (Figure 1) the strength of the microfinance impact potentially depends on the underlying income level. Therefore I repeat the hypothesis testing separate for middle- and low-income countries. This has an important policy implication as the success or the negative impact of microfinance could be predicted if the nature of its transfer mechanisms is clear.

\section{Methodology}

In any finance-and-growth analysis the primary methodological concern is to handle simultaneity, reverse causality or omitted variable bias between finance variables and dependent variables. This implies that microfinance, mainstream finance and economic growth are interrelated and driven by common economic factors that are difficult to disentangle. Addressing the reverse causality between growth and finance variables, researchers use the initial values of independent variables or instrumental variables (Levine, Loyaza, Beck, 2000). This approach, however, does not eliminate reverse causality since the initial values affect the contemporaneous values and serial correlation persists (Rousseau \& Wachtel 2000). The estimation of dynamic equations in a panel setting creates another bias when the lags of the dependent variable appear on the right-hand side as they would be correlated with the error term. Arellano and Bond (1991) proposed a linear instrumental variables technique that uses the predetermined lags of the system variables as instruments to exploit a potentially large set of overidentifying restrictions and deliver consistent coefficient estimates. The technique is also particularly relevant for an unbalanced panel with large cross- 
country observations and shorter time series, which is the case for the quite unbalanced data from Microfinance Information eXchange (MIX).

To deal with the unobserved country-specific effects that remain in the error term, Arellano and Bond (1991) introduced differencing in levels. Since the major aim is to examine the direction of causality and the nature of the transition path of microfinance to broader economy, a dynamic panel setting is more appropriate than a cross-sectional one.

I estimate separately the following equations for Granger-causality using a panel of $i=1 \ldots .102$ countries over $t=1 \ldots .14$ years $(1995-2009)$ :

$$
g_{i t}=\sum_{j=0}^{k} \alpha_{j} g_{i t-j}+\sum_{j=0}^{k} \beta_{j} m_{i t-j}+\eta_{i}+\varepsilon_{i t}
$$

where $g_{i t}{ }^{-}$captures economic growth (growth rate of real GDP); $m_{i t}$ - represents the microfinance sector (the growth rate of the gross loan portfolio held by MFIs); $\eta_{i}$ are country-specific fixed effects; $\varepsilon_{i t}$ is a random disturbance whose distribution is approximately normal; $k$ is the number of lags that is determined using Akaike (1969), Hannan-Quinn (1979) and Schwarz (1978) information criteria. The estimations reveal only the first two lags to be significant.

I use the one-step (GMM1) Arellano and Bond (1991) estimator with GMM standard errors. A two-step (GMM2) estimator is not considered as Monte Carlo simulations have shown that GMM1 in most cases produces less-biased and more efficient estimates than the GMM2 alternative (Arellano \& Bond 1991; Judson \& Owen 1997).

In equation (1) under the null hypothesis microfinance $m_{i t}$ does not Granger-cause economic growth, i.e. $\beta_{j}=0$ and economic growth is explained by its own lags only. Therefore I should be able to reject the null hypothesis to claim that $m_{i t}$ is significant and microfinance indeed causes economic growth. Contemporaneous values of $\beta_{j}$ capture instantaneous impact of microfinance on economic growth, while lagged values tell about the dynamics. Given that all the variables are in growth rates, a positive sign of $m_{i t}$ would imply the positive growth dynamics of the microfinance impact.

To estimate the indirect channels of microfinance $\left(\mathrm{H}_{2}\right.$ and $\left.\mathrm{H}_{3}\right)$ I augment the base model (1) with finance measures $f_{i t}$ captured by either money supply (M2) or banking intermediation (ratio of Private Credit to GDP) as represented below:

$$
g_{i t}=\sum_{j=0}^{k} \alpha_{j} g_{i t-j}+\sum_{j=0}^{k} \beta_{j} m_{i t-j}+\sum_{j=0}^{k} \gamma_{j} f_{i t-j}+\eta_{i}+\varepsilon_{i t}
$$


Model (2) allows to judge how microfinance is transferred to growth controlling for finance measures. Next, I introduce interaction terms of microfinance with money (microfinance portfolio $\bullet \mathrm{M} 2$ ) and mainstream banking (microfinance portfolio $\bullet$ PCredit):

$$
g_{i t}=\sum_{j=0}^{k} \alpha_{j} g_{i t-j}+\sum_{j=0}^{k} \beta_{j}(m \bullet f)_{i t-j}+\sum_{j=0}^{k} \chi_{j} m_{i t-j}+\sum_{j=0}^{k} \gamma_{j} f_{i t-j}+\eta_{i}+\varepsilon_{i t}
$$

The estimation of microfinance indirect links in specifications (2) and (3) trace how microfinance is transmitted to growth when it enters independently and through interaction with financial sector variables. The sum of $\left(\beta_{j}+\chi_{j}\right)$ coefficient estimates represents the total effect of the microfinance impact.

Finally, to control for a potential feedback effect running from macroeconomic fundamentals to microfinance I perform the following Granger-causality test in the reverse direction:

$$
m_{i t}=\sum_{j=0}^{k} \alpha_{j} m_{i t-j}+\sum_{j=0}^{k} \beta_{j} g_{i t-j}+\eta_{i}+\varepsilon_{i t}
$$

I estimate all specifications for the whole sample and separately for middle- and low-income countries. $^{2}$ The original income group classification is according to the World Bank methodology.

\subsection{Robustness and sensitivity analysis}

First I employ a broad definition of money (M3) in addition to the base (M2). By employing M3 I attempt to control for the presence of large and mature MFIs in the sample as the 30 biggest institutions serve $75 \%$ of all registered microfinance clients. It is assumed that large MFIs better integrate with national financial systems and therefore trigger significant increase in money supply captured by M3.

For the microfinance variable $m_{i t}$ that is primarily captured by the growth rate of microfinance loan portfolio I employ an alternative measure - the growth rate of the total number of active clients. These two measures characterize the main aspects of microfinance outreach: whether it expands by offering more small size loans (depth) or by servicing more clients (extent).

Given a priori ambiguous relationship of MFIs and commercial banks as specified in $H_{3}$, I employ cross-section analysis complementary to the Granger-causality framework. The nature

\footnotetext{
2 The panel contains only three high-income countries (Hungary, Slovakia, Trinidad and Tobago), therefore for consistency purposes I exclude them from the estimations. A complete list of participating countries is provided in Appendix II.
} 
of MFIs and banks co-existence is assessed by the strength of their demographic (the number of ATMs and bank branches per 100,000 inhabitants) and geographic (the number of ATMs and bank branches per 100,000 square kilometers) penetration indicators.

Finally I perform the robustness check and repeat all steps in the empirical analysis by excluding outliers. The procedure ensures that obtained results are not driven by top biggest MFIs which potentially skew the dataset.

\section{Data}

The primary data source for microfinance variables comes from the Microfinance Information eXchange (MIX), which provides unique and complete panel data for MFIs that are willing to report. Important to note is that the quality of the information reported by MFIs is closely monitored and therefore it is not treated as self-reported. The MIX employs a diamond system and allocates reporting MFIs into one-through five-diamond categories based on the amount and reliability of information reported. In contrast to other empirical papers I collect the data for all MFIs and do not truncate the sample by taking only top 4 or 5 diamond holders. This helps to avoid $26 \%$ reduction in the sample size and construct a representative panel. The data quality and reliability is yet ensured. ${ }^{3}$

The time span of the panel is 1995-2009, which is rather unbalanced for most of the countries. Since the database contains indicators by institutions, for the country-level analysis I construct a panel taking time averages of 1433 MFIs pooling them to 102 countries. The description of the panel across geographic and income groups is summarized in Table 1.

Table 1. Description of the panel, number of countries (total observations)

\begin{tabular}{|c|c|c|c|c|c|}
\hline & Low Income: & Middle Income: & High Income: & \multicolumn{2}{|c|}{ Total: } \\
\hline East Asia and the Pacific & $4 \quad(61)$ & $7 \quad(106)$ & & 11 & $(167)$ \\
\hline Europe \& Central Asia & $(45)$ & $17(256)$ & $2(30)$ & 22 & $(331)$ \\
\hline $\begin{array}{l}\text { Latin America \& the } \\
\text { Caribbean }\end{array}$ & $(15)$ & $18(272)$ & $1(15)$ & 20 & $(302)$ \\
\hline $\begin{array}{l}\text { Middle East \& North } \\
\text { Africa }\end{array}$ & $(15)$ & $(107)$ & & 8 & $(122)$ \\
\hline South Asia & $4 \quad(60)$ & $(30)$ & & 6 & $(90)$ \\
\hline Sub-Saharan Africa & $28(422)$ & $7 \quad(106)$ & & 35 & $(528)$ \\
\hline Total: & $41(618)$ & $58(877)$ & $3(45)$ & 102 & $1540)$ \\
\hline
\end{tabular}

\footnotetext{
${ }^{3}$ The financial, operational and social performance data collection on microfinance institutions goes through a comprehensive and hands-on scrubbing and standardization process by MIX analysts who review the data for outliers, extremes or inconsistencies. The analysts also double check against source documents such as audits and ratings, and standardize data according to internationally accepted accounting standards to provide for more useful intra-regional comparison. MIX is IFRS compliant and follows the SEEP framework for financial standards. More than $70 \%$ of the data is backed up by source documentation, such as audits and ratings. [Retrieved from MIX http://www.mixmarket.org/Data_Review_Process]
} 
Despite the quite representative nature of the MIX dataset there are few limitations. The first drawback is that MIX remains voluntary and therefore only those MFIs that are willing to share their information are captured. Second, the 30 biggest MFIs serve $75 \%$ of all registered microfinance clients, therefore MIX data is potentially skewed towards commercially oriented microfinance institutions looking for external financing (Honohan, 2004; Vanroose \& D'Espallier, 2009). These limitations should be taken into account when interpreting the obtained results.

To ensure the validity of the dynamic panel estimation the data should have sufficient country and year variation. Figure 3 depicts these variations in the microfinance loan portfolio, which differ greatly between middle- and low-income groups as well as over the time span (1996-2000, 2001-2005 and 2006-2009).

Figure 3: Microfinance loan portfolio, country/year variation (with and without outside values)
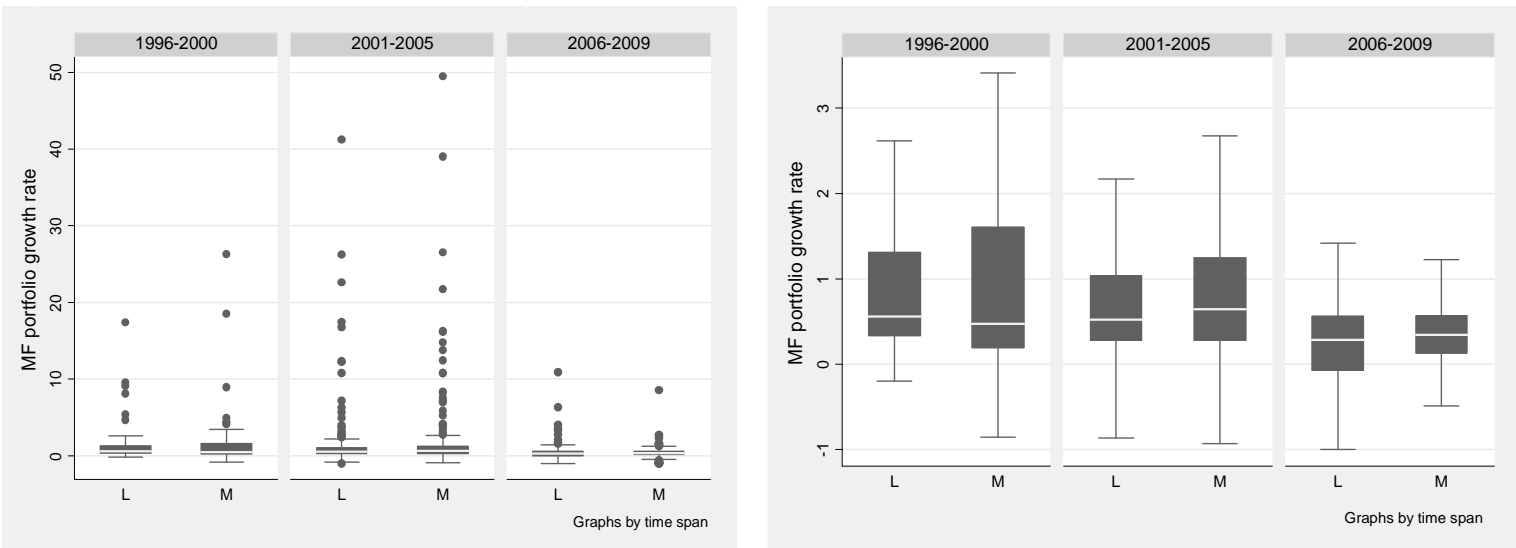

The remaining data on monetary aggregates (M2, M3) are obtained from IMF International Financial Statistics. Banking indicators (ratio of private credit, margin, concentration) are from Beck and Demirgüç-Kunt (2009) dataset. Additional measures of bank geographical and demographic penetration indicators are downloaded from Beck, Demirgüç-Kunt, Peria (2007). For a complete list of variables and their exact definitions, refer to Appendix I. Summary statistics of all variables is presented in Table 2. Table 3 is a complementary summary extended by income groups.

\section{Results}

\subsection{Evidence of the impact}

First I perform pooled OLS, random and fixed effect estimations. I also analyze between and within-country variation. Knowing the potential bias of OLS, I am nevertheless interested in 
seeing whether the growth rate of the microfinance loan portfolio has any impact on economic growth without using instruments. The results indicate that only the first lag of the microfinance portfolio has a positive significant impact for the whole sample and a negative contemporaneous impact for middle-income countries. For low-income countries in particular there is no impact and moreover the sign is reversed. I also perform the Hausman test and was able to reject the random effects model at the $1 \%$ significance level, thus confirming the validity of the fixed effect model that removes unobserved country fixed effects.

The results of Arellano and Bond (1991) instrumental variable fixed effect estimations are presented in Table 4. The table reports the coefficient estimates for models A through $G$ representing regression equations (1), (2) and (3) respectively with GDP growth as a dependent variable.

The primary observation is that microfinance causes economic growth through lagged value (model A) which supports the first hypothesis $\left(H_{1}\right)$. One percent increase in MFI loan portfolio is associated with 0.0013 percentage points increase in economic growth. The result is significant at $1 \%$. The Sargan test, however, is fragile with $0.057 \mathrm{p}$-value so I am able to confirm the validity of the instruments only at the $10 \%$ confidence level.

The impact of microfinance on money supply is captured in models B, C and D based on the second hypothesis $\left(H_{2}\right)$. The microfinance own effect $\left(\mathrm{MF}, \mathrm{MF}_{-1}\right)$ is negative. Despite the fact, the total effect, which is a sum of own and partial effects $\left(\mathrm{M} 2 \bullet \mathrm{MF}, \mathrm{M} 2 \cdot \mathrm{MF}_{-1}\right)$ is positive and significant in both B and D specifications. Supporting initial hypothesis an increase in microfinance loan portfolio is strongly associated with an increase in money circulation. Microfinance institutions therefore play an important role by decreasing the share of shadow economy and mobilizing the assets of low-income households.

The second part of the Table 4 reports the results of microfinance indirect channel to economic growth based on its interaction with commercial banks. The impact of microfinance is robust and transferred mostly by lagged values (models $E, F$ and G). Based the third hypothesis $\left(\mathrm{H}_{3}\right)$ the relationship of banks and micro-banks could be either positive or negative depending whether they act in a partnership or compete fiercely. Parameter estimate of the interaction term of the two is negative and robust (model F) suggesting about their rivalry or different rates of growth. However, this effect vanishes once we control for microfinance total effect (model G). Given such ambiguity additional robustness analysis is important.

Next I re-estimate the same models splitting the sample by income groups. For comparability purposes I combine the results for the whole and sub-samples in Table 5. The results indeed differ by income groups, confirming the original hypothesis of diverse 
transmission channels with regard to the development stage of the country. While microfinance direct transfer to growth is positive and significant for both middle and lowincome countries the transfer dynamics is heterogeneous. The impact of microfinance is immediately absorbed in low-income countries through its contemporaneous values, thus supporting the market failure hypothesis. There is no tangible evidence of indirect channels for low-income countries, suggesting a low level of integration of microfinance with mainstream finance. There are also different patterns of microfinance interaction with commercial banks given the income level. As such, only microfinance's own effect is found to be significant once we split the sample by income groups (Table 5, models D and G).

To address the potential feedback effect I perform a Granger-causality test running from macroeconomic fundamentals to microfinance (Table 6). There is no feedback effect as the Sargan test invalidates the instruments and the results are consistent when repeating the estimation separate for each income group. This indeed verifies the robust direction of causality running from microfinance to economic growth.

I perform number of sensitivity tests using different measures of the model variables. First, I tried a different measure of microfinance: the growth rate of the number of clients. There is no significant impact through clients' growth and therefore the effect of microfinance is better captured by loan portfolio. Overall loan portfolio of MFIs grows faster than number of the borrowers (Table 2 and 3). Microfinance institutions therefore expand by issuing larger loan amounts and smaller outreach, which indicates a greater emphasis of MFIs on financial rather than social objectives.

Second, I re-estimate the impact of microfinance on money circulation using a broader definition of money, i.e. M3. According to the results, microfinance is better captured through broader measures of money supply (M3). A partial explanation is provided by the specific nature of the database, which is skewed more towards the largest MFIs that better manage to integrate with national financial systems.

Third, considering the skewed nature of the panel, I performed a robustness check and repeat all the procedures excluding the loan portfolio of the 30 biggest MFIs. The results on the impact of microfinance ( $H_{1}$ and $H_{2}$ hypothesis) remain consistent with the initial findings.

\subsection{Microfinance and the market structure}

The obtained results on interaction of MFIs with banks signal that indirect channels should be investigated more and should be done so beyond a Granger-causality framework. In support of the earlier discussion on positive/negative relationship between two financial 
intermediaries I perform a cross-sectional analysis using bank penetration indicators: geographical /demographical density of ATMs and bank branch. The variables are available only for year 2003 in Beck, Demirgüç-Kunt, Peria (2007). I use bank concentration and net interest margin as additional control variables.

The obtained results ${ }^{4}$ indicate a positive significant impact of geographical branch penetration on microfinance portfolio in levels, though no impact for the growth rate of the microfinance portfolio. The rather small sample and country versus MFI level data plague the results. Therefore a promising avenue of future research could be to analyze the capacity of microfinance institutions to change the market structure of financial intermediation. The framework of spillover effects or external financing needs could be used. The latter is based on Rajan and Zingales (1998), Cetorelli and Gambera (2001) seminal works where the robust impact of banking market structure on growth is presented exploiting cross-country crossindustry variation.

\subsection{Implications of results}

Interpreting the obtained results, it is important to ensure their external validity. As such, there are three important conclusions to draw:

Diversity of channels: The observed different patterns of microfinance for low and middle-income countries, both in sign and the dynamics (through contemporaneous values and the lags) imply that there are different transmission channels. However, the diversity of transfer mechanisms could reflect different stages of microfinance industrialization which consist of evolution, expansion and then consolidation of MFIs. Complete industrialization of microfinance is a long process and requires substantial public reforms, enormous subsidies, deep transformations in government decision-making. It also requires an acceptance of microfinance as a separate segment which is in contrast to the mentality of a heavy subsidized lending or an extensive reliability on donor funds (Morduch, 1999; Hulme \& Moore, 2005). Microfinance pioneering countries such as Bangladesh, India and Indonesia have passed through long decades of such deep transformations. Grameen models originated in these countries have been replicated vastly in both the developed and developing parts of the world as success stories (Amin, 2003; Hulme \& Moore, 2005; Martowijoyo, 2007). However, a direct and blind application of these models in different contexts and different development stages posits serious hazards for the long-term stability of not only the microfinance segment but the broader financial system. A vivid example is the new wave of commercial

\footnotetext{
${ }^{4}$ These results are not presented in this version and are available upon request from the author.
} 
microfinance models promoted in the transition economies of Southeast Europe and particularly in 1990s post-war Bosnia and Herzegovina. Originally seen as one of the most successful donor interventions in the region, today's reality suggests that commercial microfinance in Bosnia may well have undermined, if not largely destroyed, the prospects for sustainable socio-economic development trajectories in the region (Bateman, 2007). Oversaturated credit markets that triggered cross-subsidization, delinquency spikes and excessive risk taking coupled with the 2008 financial crisis led to an almost $40 \%$ reduction in microfinance operations in Bosnia and an overall unpleasant experience (Mujkovic, 2010). Acknowledging such a massive and devastating potential of industrialized microfinance, a better understanding of its transfer mechanisms is needed.

Negative effects: Most of the estimations reveal a negative sign of the microfinance interaction with banking indicators. This could reflect different growth dynamics, evidence of negative externalities or spillover effects. An important aspect of the microfinance indirect channel is perceived through intensified competition between MFIs that largely fall aside of prudent regulation and therefore create harmful externalities. Analyzing such phenomena in Bangladesh, East Africa and Central America, McIntosh and Wydick (2005) derive that asymmetric information between the lender over borrower quality and indebtedness has been a serious issue in these countries. Intensified competition between MFIs just exacerbates this information asymmetricity and most impatient borrowers begin to obtain multiple loans, thus creating negative externalities.

Further, certain estimations reveal a negative interaction of microfinance with the monetary base. This might hint at another "poisoning effect" of microfinance through an increased level of non-cash operations that most of the MFIs still run. Moreover, a negative sign of interaction of microfinance may indicate its cyclical or countercyclical influence in times of macroeconomic crises. For example, microfinance was acting as a shock-absorber amidst severe economic collapse in Indonesia between 1998-2000 while there was the opposite situation in Bolivia, where microfinance declined even more severely than the national economy during hard times (Marconi \& Mosely 2005). The message is that among microfinance transfer mechanisms the indirect channel should be explored more.

Economic significance: Majority of the discussion in this paper evolve around the identification of the direction of causality between microfinance and macroeconomic fundamentals. The economic significance of the parameter estimates, however, is infinitesimal and has not been emphasized much. While the direction of the causal 
relationship and transfer mechanism has important policy implications a greater attempt should be made in the future to measure the actual magnitudes of these channels.

\section{Conclusions}

The rapid expansion of microfinance over the recent decades signals that alternative means of financing could play a significant role in mainstream finance and economic growth. Moreover, drastic movements in the microfinance industry towards prudential regulation and commercialization imply that microfinance should not be perceived as a marginalized sector of informal intermediation but rather that it constitutes a lower-end segment of the broader financial system.

Observing significant variations in microfinance patterns across countries as well as addressing the lack of research on the microfinance impact on economic growth, first, I define a conceptual framework for transmission channels where microfinance is seen as a new pillar. Second, I define an appropriate empirical methodology to test the direction of causality, which to date remains ambiguous. Rather than measuring the statistical impact of microfinance, I shed light on its dynamics and the nature of the transmission path, thus judging the interaction terms and the growth rates of the variables over the maximum length the microfinance data allows.

There is evidence of Granger-causality running directly from microfinance to economic growth, however the transfer mechanisms differ by income group and therefore by the development stage of the country. The derived heterogeneity of the channels complies with the observed patterns across countries and the existing empirical findings. However, it might also capture different stages of microfinance industrialization. This in turn justifies why the highly promoted "microfinance success models" cannot be replicated and adapted directly in another environment with varying initial levels and economic development conditions.

Microfinance indirect transfer mechanisms are captured through the interaction with monetary base and commercial banks. The nature of these interactions hints at microfinance negative externalities, spillovers, competition effects and (counter) cyclical influence in times of macroeconomic crises. Real world examples, however, suggest an ambiguous direction of these interactions, thus motivating further research in this domain. 


\section{References}

Ahlin, C., Lin, J., \& Maio, M. (2010, April). Where does microfinance flourish? Microfinance institution performance in macroeconomic context. Journal of Development Economics, 1-16.

Amin, S., Ashok, R., \& Giorgio, T. (2003). Does microcredit reach the poor and vulnerable? Evidence from Northern Bangladesh. Journal of Development Economics, 70 (1), 59-82.

Arellano, M. \& Bond, S. (1991). Some tests of specification for panel data: Monte Carlo evidence and an application to employment fluctuations. Review of Economic Studies, 58 (4), 277-97.

Barr, M. (2005). Microfinance and financial development. Michigan Journal of International Law, 26 (1), 271 - 295.

Bateman, M. (2007, July). Undermining sustainable development with commercial microfinance in Southeast Europe. Development \& Transition, 7 (1), 2-4.

Beck, T., \& Demirgüç-Kunt, A. (2009). Financial institutions and markets across countries and over time: Data and analysis. World Bank Policy Research Working Paper, No. 4943, 1-43.

Beck, T., Demirgüç-Kunt, A., \& Maksimovic, V. (2004). Bank competition and access to finance: International evidence. Journal of Money, Credit and Banking, 36 (3), 34-78.

Beck, T., Demirgüç-Kunt, A., \& Peria, M. (2007). Reaching out: Access to and use of banking services across countries. Journal of Financial Economics, 85 (1), 234-266.

Caudill, B., Gropper, D., \& Hartarska, V. (2009). Which microfinance institutions are becoming more cost effective with time? Evidence from a mixture model. Journal of Money, Credit and Banking, 41(4), 651-672.

Cetorelli, N. \& Gambera, M. (2001). Banking market structure, financial dependence and growth: International evidence from industry data. The Journal of Finance, 56 (2), 23-59.

Chen, G., Rasmussen, R., \& Reille, X. (2010). Growth and vulnerabilities of microfinance. CGAP Focus Note, No. 61, 1-15.

Cull, R., Demirgüç-Kunt, A., \& Morduch, J. (2009). Banks and microbanks. World Bank Policy Research Working Paper, No. 5078, 1-44.

Dalal, A., Morduch, J., Chaia, A., Goland, T., Gonzalez, M., \& Schiff, R. (2009, October). Half the world is Unbanked. Financial Access Initiative Framing Note, 1-16.

Delfiner, M., \& Peron, S. (2007, October). Commercial banks and microfinance. Munich Personal RePEc Archive (MPRA) Paper, No.10229, 1-32.

Judson, R., \& Owen, A. (1997). Estimating dynamic panel data models: A practical guide for macroeconomists. Board of Governors of the Federal Reserve System Finance and Economics Discussion Series, 97(3), 234-279. 
Hartarska, V. (2005). Governance and performance of microfinance organizations in Central and Eastern Europe and the Newly Independent States. World Development, 33(2), 1627 1643.

Hartarska, V., \& Nadolnyak, D. (2007). Do regulated microfinance institutions achieve better sustainability and outreach? Cross-country evidence. Applied Economics, 39(2), 12071232 .

Hartarska, V., \& Nadolnyak, D. (2008). An impact analysis of microfinance in Bosnia and Herzegovina. World Development, 36(1), 2605-2649.

Hannan, E., \& Quinn, B. (1979). The determination of the order of an autoregressive. Journal of Royal Statistical Society, 41(4), 190-195.

Hermes, N., Lensink, R., \& Meesters, A. (2009). Financial Development and the Efficiency of Microfinance Institutions. Available at SSRN: http://ssrn.com/abstract=1396202

Honohan, P. (2004). Financial sector policy and the poor: selected findings and issues. World Bank Policy Research Working Paper, No. 43, 1-47.

Honohan, P. (2008). Cross-country variation in household access to financial services. Journal of Banking \& Finance, 5(4), 1-8.

Hulme, D., \& Arun, T. (Eds.). (2008). Microfinance: A reader. London, UK: Routledge.

Hulme, D., \& Moore, K. (2005). Why Has Microfinance Been a Policy Success? [PowerPoint slides]. ESRC Seminar 'Statecraft in the South: Public Policy Success in Developing Countries', University of Manchester, May 20, 2005.

Kai, H., \& Hamori, Sh. (2009, September). Micronance and inequality. Munich Personal RePEc Archive (MPRA) Paper, No. 1757, 1-57.

King, R., \& Levine, R. (1993). Finance and growth: Schumpeter might be right. Quarterly Journal of Economics, 108 (3), 717-737.

La Porta, R., Lopez-de-Silanes, F., Shleifer, A., \& Vishny, R. (1998). Law and finance. Journal of Political Economy, 106 (6), 1113-1155.

Levine, R. (2004). Finance and growth: Theory and evidence. NBER Working Paper, (10766), 1-98.

Levine, R., Loyaza, N., \& Beck, T. (2000). Financial intermediation and growth: Causality and causes. Journal of Monetary Economics, 46 (8), 31-77.

Martowijoyo, S. (2007). Indonesian microfinance at the crossroads caught between popular and populist policies. Essays on Regulation and Supervision, (No. 23), CGAP and IRIS Center, University of Maryland.

Marconi, R., \& Mosley, P. (2005). Bolivia during the global crisis 1998-2004: Towards a macroeconomics of microfinance. Sheffield Economic Research Paper Series, No. 2057, $1-45$. 
Marulanda, B., \& Otero, M. (2005). The profile of microfinance in Latin America in 10 years: Vision and characteristics. Retrieved from Acciòn International, Boston: http://www.insme.org/documents/Microfinance_Profile_Latin_America.pdf

McIntosh, C., \& Wydick, B. (2005). Competition and microfinance. Journal of Development Economics, 78 (7), 271-298.

Microcredit Summit Campaign (2009). The state of the microfinance institutions and their clients' world-wide. Retrieved from: http://www.syminvest.com/market/news/microfinance/state-of-the-microcredit-summitcampaign-report-2009-100-million-of-the-worlds-poorest-reached-withmicrocredit/2009/1/26/1439

Morduch, J. (1999). The role of subsidies in microfinance: evidence from the Grameen Bank. Journal of Development Economics, 60 (1), 229-248.

Mujkovic, A. (2010) Microcrediting in Bosnia and Herzegovina: What went wrong? Retrieved from Microfinance Gateway Publications, CGAP: http://www.microfinancegateway.org/p/site/m//template.rc/1.9.42370

Rajan, R., \& Zingales, L. (1998). Financial dependence and growth. American Economic Review, 88 (3), 559-86.

Ravallion, M. (2001). Growth, inequality, and poverty: Looking beyond averages. World Development, 29 (11), 23-49.

Rhyne, E., \& Lopez, C. (2003). The service company model: A new strategy for commercial banks in microfinance. Accion's InSight Series, No. 6.

Rhyne, E., \& Otero, M. (2006). Microfinance through the next decade: Visioning the who, what, where, when and how. Retrieved from Global Microcredit Summit 2006: http://www.microcreditsummit.org/papers/Plenaries/RhyneOtero.pdf

Rousseau, P., \& Wachtel, P. (2000, December). Equity markets and growth: Cross country evidence on timing and outcomes, 1980-95. Journal of Banking and Finance, 24, 19331957.

Vanroose, A. (2007). Microfinance and its macro-environment. MicroBanking Bulletin, No. $14,22-24$.

Vanroose, A. (2008). What macro factors make microfinance institutions reach out? Solvay Business School Working Paper No. 08/036, 1-28.

Vanroose, A., \& D'Espallier, B. (2009). Microfinance and financial sector development. Solvay Business School Working Paper No. 09/040, 1-38. 
Appendix I: Description of the variables, source and span

\begin{tabular}{|c|c|c|}
\hline Variable: & Description: & Source and span: \\
\hline \multicolumn{3}{|c|}{ Microfinance Indicators: } \\
\hline MFp & $\begin{array}{l}\text { Loan portfolio, gross: All outstanding principals due for all } \\
\text { outstanding client loans regardless of product or client type. This } \\
\text { includes current, delinquent, and renegotiated loans, but not loans } \\
\text { that have been written off. It does not include interest receivable. } \\
\text { Being a "stock" Balance Sheet item the loan portfolio is } \\
\text { converted from local currency to USD using period ending rates. } \\
\text { Unit of measure: USD. } \\
\text { Total Number of Active Borrowers: The number of individuals or } \\
\text { entities who currently have an outstanding loan balance with the } \\
\text { MFI or are primarily responsible for repaying any portion of the } \\
\text { Loan Portfolio, Gross. Individuals who have multiple loans with } \\
\text { an MFI is counted as a single borrower. }\end{array}$ & $\begin{array}{l}\text { Microfinance Information } \\
\text { eXchange. } \\
\text { Span: } 1995-2009,104 \text { countries }\end{array}$ \\
\hline \multicolumn{3}{|c|}{ Banking Indicators: } \\
\hline $\begin{array}{l}\text { CONCENTR } \\
\text { MARGIN }\end{array}$ & $\begin{array}{l}\text { Private Credit as a ratio of GDP: Private credit by deposit money } \\
\text { banks and other financial institutions to GDP, calculated using } \\
\text { the following deflation method. Raw data are from the electronic } \\
\text { version of the IMF's IFS, October } 2008 \text {. } \\
\text { Bank Concentration: Assets of three largest banks as a share of } \\
\text { assets of all commercial banks. Fitch's BankScope database. } \\
\text { Net Interest Margin: Accounting value of bank's net interest } \\
\text { revenue as a share of its interest-bearing (total earning) assets. } \\
\text { Fitch's BankScope database. }\end{array}$ & $\begin{array}{l}\text { Beck and Demirgüç-Kunt (2009). } \\
\text { Span: 1960-2007, } 103 \text { countries }\end{array}$ \\
\hline $\begin{array}{l}\text { ATMdemo } \\
\text { ATMkm } \\
\text { Branchdemo } \\
\text { Branchkm }\end{array}$ & $\begin{array}{l}\text { Number of ATMs per } 100000 \text { habitants } \\
\text { Number of ATMs per } 100000 \mathrm{~km}^{2} \\
\text { Number of Bank branches per } 100000 \text { habitants } \\
\text { Number of Bank branches per } 100000 \mathrm{~km}^{2}\end{array}$ & $\begin{array}{l}\text { Beck, Demirgüç-Kunt, Peria (2007). } \\
\text { Span: 2003, } 99 \text { countries }\end{array}$ \\
\hline \multicolumn{3}{|c|}{ Macroeconomic Indicators: } \\
\hline GDP & $\begin{array}{l}\text { Gross Domestic Product, real: Line 99BVPZF of IMF IFS and } \\
\text { Gross Domestic Product at constant prices }(2000=100) \text {, not } \\
\text { seasonally adjusted. }\end{array}$ & $\begin{array}{l}\text { IMF IFS, CD, August 2009. Span: } \\
\text { 1995-2007, } 142 \text { countries. }\end{array}$ \\
\hline M3 & $\begin{array}{l}\text { Liquid liabilities, broad money: They are the sum of currency and } \\
\text { deposits in the central bank (M0), plus transferable deposits and } \\
\text { electronic currency (M1), plus time and savings deposits, foreign } \\
\text { currency transferable deposits, certificates of deposit, and } \\
\text { securities repurchase agreements (M2), plus travelers checks, } \\
\text { foreign currency time deposits, commercial paper, and shares of } \\
\text { mutual funds held by residents. Unit of measure: as \% of GDP. }\end{array}$ & $\begin{array}{l}\text { WB WDI on-line retrieval, } \\
\text { November 2009. Span: 1995-2008, } \\
104 \text { countries }\end{array}$ \\
\hline M2 & $\begin{array}{l}\text { Money plus Quasi-Money: Comprise by the sum of currency } \\
\text { outside banks, demand deposits other than those of the central } \\
\text { government, and the time, savings, and foreign currency deposits } \\
\text { of resident sectors other than the central government. } \\
\text { Corresponds to M2; lines } 34 \text { and } 35 \text { in IMF IFS. Unit of measure: } \\
\text { billions NC. }\end{array}$ & \\
\hline
\end{tabular}


Appendix II: List of participating countries by income group and time span

\begin{tabular}{|c|c|c|c|c|c|c|c|c|c|}
\hline \multicolumn{2}{|c|}{ High Income: } & \multicolumn{4}{|c|}{ Middle Income: } & \multicolumn{4}{|c|}{ Low Income: } \\
\hline Hungary & $1994-2008$ & Albania & $1994-2008$ & Lebanon & $1994-2008$ & Afghanistan & 1994-2008 & Rwanda & 1994-2008 \\
\hline Slovakia & $1994-2008$ & Angola & 1994-2008 & Macedonia & $1994-2008$ & Bangladesh & 1994-2008 & Senegal & $1994-2008$ \\
\hline \multirow[t]{27}{*}{$\begin{array}{l}\text { Trinidad and } \\
\text { Tobago }\end{array}$} & 1994-2008 & Argentina & 1994-2008 & Mexico & $1994-2008$ & Benin & 1994-2008 & Sierra Leone & 1994-2008 \\
\hline & & Armenia & $1994-2008$ & Moldova & 1994-2008 & Burkina Faso & 1994-2008 & Tajikistan & 1994-2008 \\
\hline & & Azerbaijan & 1994-2008 & Mongolia & 1994-2008 & Burundi & 1994-2008 & Tanzania & 1994-2008 \\
\hline & & Bolivia & 1994-2008 & Montenegro & 1994-2008 & Cambodia & 1994-2008 & Togo & 1994-2008 \\
\hline & & $\begin{array}{l}\text { Bosnia and } \\
\text { Herzegovina }\end{array}$ & 1994-2008 & Morocco & 1994-2008 & $\begin{array}{l}\text { Central } \\
\text { African Rep. }\end{array}$ & 1994-2008 & Uganda & 1994-2008 \\
\hline & & Brazil & 1994-2008 & Namibia & 1994-2008 & Chad & 1994-2008 & Uzbekistan & 1994-2008 \\
\hline & & Bulgaria & 1994-2008 & Nicaragua & 1994-2008 & $\begin{array}{l}\text { Congo, D. } \\
\text { Rep. }\end{array}$ & 1995-2009 & Vietnam & 1994-2008 \\
\hline & & Cameroon & 1994-2009 & Palestine & 2009-2009 & Cote d'Ivoire & 1994-2008 & Yemen & 1994-2008 \\
\hline & & Chile & 1994-2008 & Panama & 1994-2008 & Ethiopia & 1994-2008 & Zambia & 1994-2008 \\
\hline & & China, People's & $1995-2008$ & Paraguay & 1994-2008 & Gambia & $1995-2008$ & Zimbabwe & 1994-2008 \\
\hline & & Colombia & 1994-2008 & Peru & 1994-2008 & Ghana & 1994-2008 & & \\
\hline & & $\begin{array}{l}\text { Congo, } \\
\text { Republic }\end{array}$ & $1995-2008$ & Philippines & 1994-2008 & Guinea & 1994-2008 & & \\
\hline & & Costa Rica & 1994-2008 & Poland & 1994-2008 & $\begin{array}{l}\text { Guinea- } \\
\text { Bissau }\end{array}$ & 1994-2008 & & \\
\hline & & Croatia & 1994-2008 & Romania & 1994-2008 & Haiti & 1994-2008 & & \\
\hline & & $\begin{array}{l}\text { Dominican } \\
\text { Republic }\end{array}$ & 1994-2008 & Russia & 1994-2008 & Kenya & 1994-2009 & & \\
\hline & & East Timor & 1994-2008 & Samoa & 1994-2008 & Kyrgyzstan & 1994-2008 & & \\
\hline & & Ecuador & 1994-2008 & Serbia & 1994-2008 & Laos & 1994-2009 & & \\
\hline & & Egypt & 1994-2008 & $\begin{array}{l}\text { South } \\
\text { Africa }\end{array}$ & 1994-2008 & Liberia & 1994-2008 & & \\
\hline & & El Salvador & 1994-2008 & Sri Lanka & 1994-2008 & Madagascar & 1994-2008 & & \\
\hline & & Georgia & 1994-2008 & Sudan & 1994-2008 & Malawi & 1994-2008 & & \\
\hline & & Guatemala & 1994-2008 & Swaziland & 1994-2008 & Mali & 1994-2008 & & \\
\hline & & Honduras & 1994-2008 & Syria & 1994-2008 & Mozambique & 1994-2008 & & \\
\hline & & India & 1994-2008 & Thailand & 1994-2008 & Nepal & 1994-2008 & & \\
\hline & & Indonesia & 1994-2009 & Tunisia & 1994-2009 & Niger & 1994-2008 & & \\
\hline & & Iraq & 1994-2008 & Turkey & 1994-2008 & Nigeria & 1994-2008 & & \\
\hline & & Jordan & 1994-2008 & Ukraine & 1994-2008 & Pakistan & 1994-2008 & & \\
\hline & & Kazakhstan & 1994-2009 & Uruguay & 1994-2008 & $\begin{array}{l}\text { Papua New } \\
\text { Guinea }\end{array}$ & 1994-2008 & & \\
\hline \multicolumn{2}{|c|}{ Total Countries: } & \multicolumn{4}{|c|}{58} & \multicolumn{4}{|c|}{41} \\
\hline
\end{tabular}


Table 2. Summary statistics of the variables (in growth rates, if not otherwise)

\begin{tabular}{lllllll}
\hline Variable & Description & $\mathrm{N}$ & Mean & St. Dev. & Min & Max \\
\hline $\mathrm{MFp}$ & Gross loan portfolio of MFIs & 800 & 1.32 & 3.91 & -0.99 & 49.48 \\
$\mathrm{MFb}$ & Active borrowers of MFIs & 790 & 0.93 & 3.07 & -0.99 & 38.15 \\
$\mathrm{M} 2$ & $\mathrm{M} 2$ & 1246 & 0.27 & 1.28 & -0.77 & 41.05 \\
$\mathrm{M} 3$ & $\mathrm{M} 3$ & 1129 & 0.24 & 0.55 & -0.77 & 14.53 \\
$\mathrm{PCredit}$ & ratio of private credit to GDP & 1072 & 0.05 & 0.87 & -0.98 & 2.41 \\
$\mathrm{GDP}$ & Real GDP & 1295 & 0.05 & 0.07 & -0.41 & 1.06 \\
$\mathrm{M} 2 \cdot \mathrm{MF}$ & Interaction of M2 and MFp & 760 & 0.49 & 6.28 & -104.20 & 108.34 \\
$\mathrm{M} \cdot \mathrm{MF}$ & Interaction of M3 and MFp & 718 & 0.34 & 5.04 & -104.20 & 65.29 \\
PCredit•MF & Interaction of Credit and MFp & 603 & 0.30 & 4.16 & -9.35 & 97.42 \\
ATMdemo & \# of bank branches per 100000 ppl & 48 & 10.60 & 9.63 & 0.06 & 40.10 \\
BRANCHdemo & \# of bank branches per 100000 ppl & 54 & 6.71 & 5.62 & 0.41 & 28.25 \\
ATMkm & \# of bank ATMs per 1000km 2 & 48 & 10.61 & 15.25 & 0.07 & 73.9 \\
BRANCHkm & \# of bank ATMs per 1000km ${ }^{2}$ & 54 & 8.45 & 13.39 & 0.10 & 79.17 \\
\hline
\end{tabular}

Table 3. Summary statistics of the main variables by income group (in growth rates)

\begin{tabular}{lllllll}
\hline Variables: & Income Group: & $\mathrm{N}$ & Mean & Std. Dev. & Min & Max \\
\hline MF portfolio & High & 7 & 2.16 & 5.13 & -0.15 & 13.76 \\
& Low & 310 & 1.34 & 3.82 & -1.00 & 41.24 \\
& Middle & 473 & 1.32 & 4.01 & -1.00 & 49.49 \\
MFI borrowers & High & 5 & 3.82 & 8.60 & -0.49 & 19.20 \\
& Low & 309 & 0.99 & 3.55 & -1.00 & 38.09 \\
& Middle & 466 & 0.82 & 2.38 & -1.00 & 38.15 \\
Real GDP & High & 39 & 0.06 & 0.03 & 0.00 & 0.14 \\
& Low & 513 & 0.05 & 0.08 & -0.31 & 1.06 \\
M2 & Middle & 743 & 0.05 & 0.06 & -0.41 & 0.76 \\
& High & 39 & 0.12 & 0.06 & -0.01 & 0.29 \\
& Low & 481 & 0.27 & 0.79 & -0.78 & 14.53 \\
& Middle & 726 & 0.28 & 1.55 & -0.51 & 41.06 \\
& High & 39 & 0.02 & 0.10 & -0.19 & 0.25 \\
& Low & 423 & 0.04 & 0.16 & -0.43 & 0.73 \\
& Middle & 610 & 0.06 & 0.21 & -0.99 & 2.42 \\
\hline
\end{tabular}




\section{Table 4. Microfinance direct and indirect channels, whole sample}

This table reports parameter estimates from the one-step Arellano and Bond (1991) estimator with GMM standard errors in parentheses. The dependent variable is the growth rate of real GDP, variables with subscripts denote lagged values. Microfinance is captured by the growth rate of the loan portfolio. Model A estimates the direct transfer of microfinance to economic growth based on equation (1). Models B, C and D capture the indirect channels and interactions of microfinance with M2 based on equation (2). Models E, F and G in a similar pattern estimate indirect channel when microfinance is interacted with ratio of private credit based on equation (3). All models are estimated using the Arellano and Bond (1991) instrumental variable approach.

The symbols *,** and *** denote significance at the $10 \%, 5 \%$ and $1 \%$ levels, respectively.

\begin{tabular}{|c|c|c|c|c|c|c|c|}
\hline & & \multicolumn{3}{|c|}{ Money } & \multicolumn{3}{|c|}{ Private Credit } \\
\hline & (A) & (B) & (C) & (D) & (E) & (F) & (G) \\
\hline GDP $_{-1}$ & $\begin{array}{l}0.0606 \\
(0.0445)\end{array}$ & $\begin{array}{l}0.0346 \\
(0.0401)\end{array}$ & $\begin{array}{l}0.1171 * * * \\
(0.0564)\end{array}$ & $\begin{array}{c}0.0056 \\
(0.0391)\end{array}$ & $\begin{array}{l}0.0321 \\
(0.0565)\end{array}$ & $\begin{array}{l}0.0316 \\
(0.0683)\end{array}$ & $\begin{array}{l}0.0173 \\
(0.0551)\end{array}$ \\
\hline MF & $\begin{array}{l}-0.0012 \\
(0.0019)\end{array}$ & $\begin{array}{l}-0.0019 \\
(0.0015)\end{array}$ & & $\begin{array}{l}-0.0059 * * \\
(0.0028)\end{array}$ & $\begin{array}{l}-0.0005 \\
(0.0012)\end{array}$ & & $\begin{array}{l}0.0003 \\
(0.0012)\end{array}$ \\
\hline $\mathbf{M F}_{-1}$ & $\begin{array}{l}0.0013 * * * \\
(0.0004)\end{array}$ & $\begin{array}{l}0.0014 * * * \\
(0.0004)\end{array}$ & & $\begin{array}{l}0.0016^{*} \\
(0.0009)\end{array}$ & $\begin{array}{l}0.0013^{* * *} * \\
(0.0005)\end{array}$ & & $\begin{array}{l}0.0013 * * * \\
(0.0005)\end{array}$ \\
\hline M2 & & $\begin{array}{l}0.0327 \\
(0.0199)\end{array}$ & & $\begin{array}{l}0.0285 \\
(0.0182)\end{array}$ & & & \\
\hline M2-1 & & $\begin{array}{l}-0.0067 \\
(0.0101)\end{array}$ & & $\begin{array}{l}-0.0069 \\
(0.0100)\end{array}$ & & & \\
\hline M2・MF & & & $\begin{array}{l}-0.0118^{* *} \\
(0.0053)\end{array}$ & $\begin{array}{l}0.0167^{*} \\
(0.0094)\end{array}$ & & & \\
\hline $\mathbf{M}^{\bullet} \mathbf{M F}_{-1}$ & & & $\begin{array}{l}0.0005^{*} \\
(0.0003)\end{array}$ & $\begin{array}{l}-0.0012 \\
(0.0039)\end{array}$ & & & \\
\hline PCredit & & & & & $\begin{array}{l}0.0251 \\
(0.0257)\end{array}$ & & $\begin{array}{l}0.0262 \\
(0.0259)\end{array}$ \\
\hline PCredit_-1 $_{1}$ & & & & & $\begin{array}{l}-0.0059 \\
(0.0175)\end{array}$ & & $\begin{array}{l}-0.0002 \\
(0.0164)\end{array}$ \\
\hline PCredit`MF & & & & & & $\begin{array}{l}0.0006 \\
(0.0099)\end{array}$ & $\begin{array}{l}-0.0109 \\
(0.0091)\end{array}$ \\
\hline PCredit $^{\bullet} \mathrm{MF}_{-1}$ & & & & & & $\begin{array}{l}-0.0010^{* * *} \\
(0.0004)\end{array}$ & $\begin{array}{l}0.0004 \\
(0.0033)\end{array}$ \\
\hline $\mathrm{N}$ & 569 & 544 & 557 & 544 & 423 & 434 & 423 \\
\hline Sargan (p-value) & 0.057 & 0.064 & 1.000 & 0.040 & 0.622 & 1.000 & 0.912 \\
\hline $\mathrm{AR}(2)$ (p-value) & 0.963 & 0.842 & 0.774 & 0.628 & 0.617 & 0.513 & 0.631 \\
\hline
\end{tabular}




\section{Table 5. Microfinance direct and indirect channels, by income groups}

This table reports parameter estimates from the one-step Arellano and Bond (1991) estimator with GMM standard errors in parentheses. The dependent variable is the growth rate of real GDP, variables with subscripts denote lagged values. Microfinance (MF) is captured by the growth rate of the loan portfolio. Model A estimates the direct transfer of microfinance to economic growth. Models D and G estimate the indirect channel when microfinance is interacted with M2 and the ratio of private credit, respectively.

The symbols $*, * *$ and $* * *$ denote significance at $10 \%, 5 \%$ and $1 \%$ levels respectively.

\begin{tabular}{|c|c|c|c|c|c|c|c|c|c|}
\hline & \multicolumn{3}{|c|}{ Whole Sample } & \multicolumn{3}{|c|}{ Middle Income } & \multicolumn{3}{|c|}{ Low Income } \\
\hline & (A) & (D) & (G) & (A) & (D) & (G) & (A) & (D) & (G) \\
\hline $\mathrm{GDP}_{-1}$ & $\begin{array}{l}0.0606 \\
(0.0445)\end{array}$ & $\begin{array}{l}0.0173 \\
(0.0551)\end{array}$ & $\begin{array}{l}0.0056 \\
(0.0391)\end{array}$ & $\begin{array}{l}0.0238 \\
(0.0502)\end{array}$ & $\begin{array}{l}-0.0721 \\
(0.0616)\end{array}$ & $\begin{array}{l}-0.0326 \\
(0.0438)\end{array}$ & $\begin{array}{l}0.0720 \\
(0.0900)\end{array}$ & $\begin{array}{l}0.1423 * \\
(0.0742)\end{array}$ & $\begin{array}{l}0.1701 * * \\
(0.0671)\end{array}$ \\
\hline MF & $\begin{array}{l}-0.0012 \\
(0.0019)\end{array}$ & $\begin{array}{l}0.0003 \\
(0.0012)\end{array}$ & $\begin{array}{l}-0.0059 * * \\
(0.0028)\end{array}$ & $\begin{array}{l}-0.0026 \\
(0.0018)\end{array}$ & $\begin{array}{l}-0.0008 \\
(0.0011)\end{array}$ & $\begin{array}{l}-0.0059 * * * \\
(0.0023)\end{array}$ & $\begin{array}{l}0.0057 * * \\
(0.0023)\end{array}$ & $\begin{array}{l}0.0011 \\
(0.0014)\end{array}$ & $\begin{array}{l}0.0005 \\
(0.0018)\end{array}$ \\
\hline $\mathbf{M F}_{-1}$ & $\begin{array}{l}0.0013 * * * \\
(0.0004)\end{array}$ & $\begin{array}{l}0.0013 * * * \\
(0.0005)\end{array}$ & $\begin{array}{l}0.0016^{*} \\
(0.0009)\end{array}$ & $\begin{array}{l}0.0018 * * * \\
(0.0005)\end{array}$ & $\begin{array}{l}0.0017 * * * \\
(0.0006)\end{array}$ & $\begin{array}{l}0.0028 * * \\
(0.0012)\end{array}$ & $\begin{array}{l}-0.0004 \\
(0.0007)\end{array}$ & $\begin{array}{l}-0.0001 \\
(0.0008)\end{array}$ & $\begin{array}{l}0.0001 \\
(0.0013)\end{array}$ \\
\hline M2 & & & $\begin{array}{l}0.0285 \\
(0.0182)\end{array}$ & & & $\begin{array}{l}0.0404 * * \\
(0.0204)\end{array}$ & & & $\begin{array}{l}-0.0132 \\
(0.0178)\end{array}$ \\
\hline M2 & & & $\begin{array}{l}-0.0069 \\
(0.0100)\end{array}$ & & & $\begin{array}{l}-0.0008 \\
(0.0112)\end{array}$ & & & $\begin{array}{l}-0.0350 * \\
(0.0193)\end{array}$ \\
\hline M2•MF & & & $\begin{array}{l}0.0167 * \\
(0.0094)\end{array}$ & & & $\begin{array}{l}0.0125 \\
(0.0079)\end{array}$ & & & $\begin{array}{l}-0.0016 \\
(0.0069)\end{array}$ \\
\hline $\mathbf{M} 2 \mathbf{M F}_{-1}$ & & & $\begin{array}{l}-0.0012 \\
(0.0039)\end{array}$ & & & $\begin{array}{l}-0.0048 \\
(0.0049)\end{array}$ & & & $\begin{array}{l}-0.0016 \\
(0.0069)\end{array}$ \\
\hline PCredit & & $\begin{array}{l}0.0262 \\
(0.0259)\end{array}$ & & & $\begin{array}{l}0.0020 \\
(0.0302)\end{array}$ & & & $\begin{array}{l}-0.0420 \\
(0.0302)\end{array}$ & \\
\hline PCredit $_{-1}$ & & $\begin{array}{l}-0.0002 \\
(0.0164)\end{array}$ & & & $\begin{array}{l}0.0075 \\
(0.0188)\end{array}$ & & & $\begin{array}{l}0.0455^{*} \\
(0.0258)\end{array}$ & \\
\hline PCredit•MF & & $\begin{array}{l}-0.0109 \\
(0.0091)\end{array}$ & & & $\begin{array}{l}-0.0067 \\
(0.0084)\end{array}$ & & & $\begin{array}{l}0.0295 \\
(0.0239)\end{array}$ & \\
\hline $\mathbf{P C r e d i t}^{\bullet} \mathbf{M F}_{-1}$ & & $\begin{array}{l}0.0004 \\
(0.0033)\end{array}$ & & & $\begin{array}{l}0.0001 \\
(0.0037)\end{array}$ & & & $\begin{array}{l}0.0060 \\
(0.0073)\end{array}$ & \\
\hline $\mathrm{N}$ & 569 & 423 & 544 & 348 & 258 & 347 & 219 & 164 & 195 \\
\hline Sargan (p-value) & 0.057 & 0.912 & 0.040 & 0.020 & 0.173 & 0.095 & 0.183 & 0.082 & 0.110 \\
\hline $\operatorname{AR}(2)$ (p-value) & 0.963 & 0.631 & 0.628 & 0.383 & 0.590 & 0.302 & 0.463 & 0.766 & 0.511 \\
\hline
\end{tabular}


Table 6. Granger-causality running in both directions, whole sample

This table reports parameter estimates from one-step Arellano and Bond (1991) estimator with GMM standard errors in parenthesis. The table summarizes the evidence on Granger-causality between microfinance and macroeconomic indicators, running in both directions. On the lefthand panel the dependent variable is the growth rate of the microfinance loan portfolio (MF). On the left-hand panel the dependent variables are economic growth (GDP), money (M2) and banking (PCredit). Variables with subscripts denote lagged values. All variables are in growth rates.

The symbols $* * *$ and $* * *$ denote significance at the $10 \%, 5 \%$ and $1 \%$ levels, respectively.

\begin{tabular}{|c|c|c|c|c|c|c|}
\hline Dep. variables -> & MF & MF & MF & GDP & M2 & PCredit \\
\hline MF & & & & $\begin{array}{l}-0.0012 \\
(0.0019)\end{array}$ & $\begin{array}{l}-0.0173 * \\
(0.0093)\end{array}$ & $\begin{array}{l}-0.0079 * \\
(0.0045)\end{array}$ \\
\hline $\mathrm{MF}_{-1}$ & $\begin{array}{l}0.0537^{*} \\
(0.0310)\end{array}$ & $\begin{array}{l}0.0380 \\
(0.0310)\end{array}$ & $\begin{array}{l}0.0033 \\
(0.0345)\end{array}$ & $\begin{array}{l}0.0013 * \\
(0.0004)\end{array}$ & $\begin{array}{l}-0.0019 \\
(0.0020)\end{array}$ & $\begin{array}{l}-0.0035^{* * * *} \\
(0.0012)\end{array}$ \\
\hline M2 & & $\begin{array}{l}-0.7318 \\
(0.9669)\end{array}$ & & & & \\
\hline $\mathrm{M} 2_{-1}$ & & $\begin{array}{l}-0.8859 \\
(0.7648)\end{array}$ & & & $\begin{array}{l}-0.238^{* * * *} \\
(0.045)\end{array}$ & \\
\hline GDP & $\begin{array}{l}-3.8183 \\
(6.2567)\end{array}$ & & & & & \\
\hline $\mathrm{GDP}_{-1}$ & $\begin{array}{l}0.0003 \\
(2.9114)\end{array}$ & & & $\begin{array}{l}0.041 \\
(0.041)\end{array}$ & & \\
\hline PCredit & & & $\begin{array}{l}-2.8585 \\
(2.0362\end{array}$ & & & \\
\hline PCredit $_{-1}$ & & & $\begin{array}{l}1.1865 \\
(1.3088)\end{array}$ & & & $\begin{array}{l}0.301 * * * \\
(0.045)\end{array}$ \\
\hline $\mathrm{N}$ & 569 & 551 & 423 & 569 & 551 & 423 \\
\hline Sargan (p-value) & 0.551 & 0.909 & 0.001 & 0.057 & 0.000 & 0.000 \\
\hline $\operatorname{AR}(2)(p$-value) & 0.913 & 0.907 & 0.923 & 0.963 & 0.000 & 0.893 \\
\hline
\end{tabular}




\section{Working Paper Series}

ISSN 1211-3298

Registration No. (Ministry of Culture): E 19443

Individual researchers, as well as the on-line and printed versions of the CERGE-EI Working Papers (including their dissemination) were supported from the European Structural Fund (within the Operational Programme Prague Adaptability), the budget of the City of Prague, the Czech Republic's state budget and the following institutional grants:

- Center of Advanced Political Economy Research [Centrum pro pokročilá politickoekonomická studia], No. LC542, (2005-2010);

- Economic Aspects of EU and EMU Entry [Ekonomické aspekty vstupu do Evropské unie a Evropské měnové unie], No. AVOZ70850503, (2005-2010);

- Economic Impact of European Integration on the Czech Republic [Ekonomické dopady evropské integrace na ČR], No. MSM0021620846, (2005-2011);

Specific research support and/or other grants the researchers/publications benefited from are acknowledged at the beginning of the Paper.

(c) Nargiza Maksudova, 2010

All rights reserved. No part of this publication may be reproduced, stored in a retrieval system or transmitted in any form or by any means, electronic, mechanical or photocopying, recording, or otherwise without the prior permission of the publisher.

Published by

Charles University in Prague, Center for Economic Research and Graduate Education (CERGE) and

Economics Institute ASCR, v. v. i. (EI)

CERGE-El, Politických vězňů 7, 11121 Prague 1, tel.: +420 224005 153, Czech Republic.

Printed by CERGE-EI, Prague

Subscription: CERGE-EI homepage: http://www.cerge-ei.cz

Phone: + 420224005153

Email: office@cerge-ei.cz

Web: http://www.cerge-ei.cz

Editor: Michal Kejak

Editorial board: Jan Kmenta, Randall Filer, Petr Zemčík

The paper is available online at http://www.cerge-ei.cz/publications/working_papers/.

ISBN 978-80-7343-222-5 (Univerzita Karlova. Centrum pro ekonomický výzkum a doktorské studium)

ISBN 978-80-7344-212-5 (Národohospodářský ústav AV ČR, v. v. i.) 


\section{Working Paper Series}

ISSN 1211-3298

Registration No. (Ministry of Culture): E 19443

Individual researchers, as well as the on-line and printed versions of the CERGE-EI Working Papers (including their dissemination) were supported from the European Structural Fund (within the Operational Programme Prague Adaptability), the budget of the City of Prague, the Czech Republic's state budget and the following institutional grants:

- Center of Advanced Political Economy Research [Centrum pro pokročilá politickoekonomická studia], No. LC542, (2005-2010);

- Economic Aspects of EU and EMU Entry [Ekonomické aspekty vstupu do Evropské unie a Evropské měnové unie], No. AVOZ70850503, (2005-2010);

- Economic Impact of European Integration on the Czech Republic [Ekonomické dopady evropské integrace na ČR], No. MSM0021620846, (2005-2011);

Specific research support and/or other grants the researchers/publications benefited from are acknowledged at the beginning of the Paper.

(c) Nargiza Maksudova, 2010

All rights reserved. No part of this publication may be reproduced, stored in a retrieval system or transmitted in any form or by any means, electronic, mechanical or photocopying, recording, or otherwise without the prior permission of the publisher.

Published by

Charles University in Prague, Center for Economic Research and Graduate Education (CERGE) and

Economics Institute ASCR, v. v. i. (EI)

CERGE-El, Politických vězňů 7, 11121 Prague 1, tel.: +420 224005 153, Czech Republic.

Printed by CERGE-EI, Prague

Subscription: CERGE-EI homepage: http://www.cerge-ei.cz

Phone: + 420224005153

Email: office@cerge-ei.cz

Web: http://www.cerge-ei.cz

Editor: Michal Kejak

Editorial board: Jan Kmenta, Randall Filer, Petr Zemčík

The paper is available online at http://www.cerge-ei.cz/publications/working_papers/.

ISBN 978-80-7343-222-5 (Univerzita Karlova. Centrum pro ekonomický výzkum a doktorské studium)

ISBN 978-80-7344-212-5 (Národohospodářský ústav AV ČR, v. v. i.) 